\title{
Economic Evaluation of Early Peach (Prunus Persica L. batsch) Commercial Orchard under Different Irrigation Strategies
}

\author{
Jesus García García*, Jose García Brunton \\ Instituto Murciano de Investigación y Desarrollo Agrario y Alimentario (IMIDA), La Alberca, Murcia, Spain \\ Email: ${ }^{*}$ jose.garcia21@carm.es
}

Received May 8, 2013; revised June 15, 2013; accepted July 1, 2013

Copyright (C) 2013 Jesus García García, Jose García Brunton. This is an open access article distributed under the Creative Commons Attribution License, which permits unrestricted use, distribution, and reproduction in any medium, provided the original work is properly cited.

\begin{abstract}
The main aim of this paper is to evaluate the economic response of different irrigation water levels in an early ripening peach variety. In this sense, we evaluate the economics and overall water use efficiency. The test is designed with 4 irrigation water strategies. The economic indices used that use net margin show that all the alternatives are viable although the control with its Net Margin (NM)/Cost (C) of 23.6\% is of particular note. This is followed by R50, the highest deficit treatment, with an $\mathrm{NM} / \mathrm{C}$ of $16.0 \%$. The mean production cost was almost identical in the optimal treatment (control) and the R50 deficit treatment, $€ 0.69$ and $€ 0.70$, respectively. R50 was the most efficient treatment, with a Water Use Efficiency (WUE) of $5.54 \mathrm{~kg} \cdot \mathrm{m}^{-3}$. The $\mathrm{NM} \mathrm{m}^{-3}$ as economic efficiency index was the greatest in the control $\left(0.74 € \mathrm{~m}^{-3}\right)$, followed by R50 $\left(0.65 € \mathrm{~m}^{-3}\right)$, while the other treatments were far from these figures. Peach cultivation generates a lot of employment and in all cases the Number of Agricultural Jobs (NAJ) ha ${ }^{-1}$ was around 0.59 . As regards the social efficiency of water, the deficit treatments we applied reached high values in this respect, reaching 181 NAJ $\mathrm{hm}^{-3}$ in R50.
\end{abstract}

Keywords: Water Use Efficiency; Costs; Economics; Break Even Point; Peach

\section{Introduction}

The European Union is responsible for $27.1 \%$ of the world's production of peaches in $16.7 \%$ of the worldwide area dedicated to the same. Spain is the second largest grower within the EU [1]. Spanish production is characterized for its precocity, majority being in peach and spends around $20 \%$ for industry [2].

The concentration of supply in summer months and competition from non-EU countries have led to European producers bringing forward production from July-September to earlier in the year. Accompanying this move, the use of drip irrigation has become widespread in southern European countries to ensure high yields of quality fruit, especially in areas where water is scarce. Such is the case in the region of Murcia [3], where, in the same area as before, this technology has enabled growers in the last 25 years to double their production of peaches. One of the great advantages of localized irrigation is the improved water use efficiency that has been attained,

${ }^{*}$ Corresponding author. which has meant that peach can be grown in areas where water is scarce. In this respect, the contributions of and [4] were pioneering in the technique of Regulated Deficit Irrigation (RDI) in peach. Despite differences in the findings due to climatic and edaphic factors, the rootstock used etc. [5], many studies have demonstrated that, apart from the savings and increased efficiency that are possible, RDI rationalizes water use [6,7], controlling tree vigour, decreasing pruning costs and diminishing pests and disease [8]. Practically all RDI studies in peach have been made in medium or long flowering-maturation cycle varieties where the postharvest period is short or minimal [9-13]. Phase II of fruit growth (pit hardening) is the time when deficit irrigation is most beneficial since neither the quantity or quality of the resulting fruit is affected [6].

As mentioned, Spanish peach growers are increasingly concentrating on early or mid (May-June) ripening varieties, the corollary being that the postharvesting stage is very long. Although studies on RDI in such varieties are scarce, it is evident that the postharvest stage is most 
suitable for submitting trees to a water deficit regime [14, 15], since there is no fruit involved, which reduces water demand and the possible depressive effects on future production are minimal.

The special climatic conditions of the Region of Murcia (hereafter Murcia) have enabled peach and nectarine plantations to be concentrated in areas that enjoy mild winter and spring weather, where growers can plant early ripening varieties that have little need for cold, thus minimizing market competition and lengthening the presence also. All these varieties are destined for the European market, while the socio-economic importance of the crop in the province has grown considerably [16]. In Spain and Murcia, in particular, relatively high prices can be charged as a result of the added value represented by the crop's earliness. Another remarkable characteristic is the high need of labour [17]. While the particular circumstances of each producing country determines overall production costs, the greatest proportion of such costs, in general, is associated with the workforce necessary and, in peach, the main tasks in this respect are related with pruning, thinning and harvesting $[1,16,18]$.

Rainfall and evaporation in the growing area under study establish strict limitations as regards the water balance and water resources available. In the Segura river basin and in the whole region of Murcia there is a serious problem for agriculture in this respect $[19,20]$. Since water limits the area available for irrigation in the most suitable productive conditions, the election of the most suitable growing options must be based on socio-economic criteria $[21,22]$. Hence, the economic efficiency differential related with water will orientate the producer to choosing the option that maximizes profit per unit of water used $[23,24]$.

The main aim of the project "Economic and agronomic effects, and controlling pests and diseases at different levels of irrigation in early peach crops" is to evaluate in the environmental conditions of south-eastern Spain, the economic response of different irrigation water levels in an extra-early ripening peach variety. In this sense, we evaluate the economics and overall efficiency (productive, economic and social) of water use.

\section{Material and Methods}

\subsection{Field Conditions, Plant Material, and Irrigation Treatments}

The experiment was carried out in a plot growing the extra-early nectarine variety Casasil $\AA^{\circledR}$, which, in Murcia, ripens during the first week of May. The plot is situated in a commercial orchard of the area known as "PeraPera" in Blanca Blanca $\left(38^{\circ} 12^{\prime} \mathrm{N}, 1^{\circ} 20^{\prime} \mathrm{W}, 245 \mathrm{~m}\right)$, one of the several areas dedicated to early-ripening fruit trees in Murcia. Adult (8 year old) trees grafted on hybrid almondxpeach rootstock (GF 677) and in full production were used. The tree were planted in a $5.5 \times 3.5 \mathrm{~m}$ framework (520 plants/ha) and drip irrigated (4 emitters per tree, $\left.41 \cdot h^{-1}\right)$. Four different irrigation treatments were studied (Table 1). The test designed with 4 irrigation water strategies:

+ Control: irrigation level used on the commercial farm.

+ R 150: $100 \%$ of reference evapotranspiration, Eto, until harvesting and $150 \%$ Eto during the postharvest period, calculated according to the recommendations of the Murcia Agrarian Information System (SIAM. www. imida.es).

+ R 75: $100 \%$ Eto until harvesting and $75 \%$ Eto during the postharvest period.

+ R 50: 100\% Eto until harvesting and 50\% Eto during the postharvest period.

Each sector dedicated to a particular treatment had a meter to record the real amount of water applied. Each treatment was divided into four completely randomized plots (four repetitions of the basic plot). The basic plot comprised 3 parallel rows of 8 trees. Measurements were made in the 6 central trees, while the outermost trees acted as guard trees to avoid the effects of the neighbouring treatments. The soil moisture levels of each treatment were measured and controlled by a Diviner $2000^{\circledR}$ probe (one per treatment).

Rainfall was not considered in the calculation of

Table 1. Yearly water supplied, at each irrigation treatment, Eto and rainfall in the period (2007-2010).

\begin{tabular}{cccccc}
\hline Irrigation $\left(\mathrm{m}^{3} \cdot \mathrm{ha}^{-1}\right)$ & 2007 & 2008 & 2009 & 2010 & average \\
\hline Control & $5230(29 \%)$ & $4685(29 \%)$ & $4491(34 \%)$ & $4111(41 \%)$ & $4629(33 \%)$ \\
R150 & $5230(29 \%)$ & $5894(29 \%)$ & $5193(30 \%)$ & $4416(38 \%)$ & $5183(31 \%)$ \\
R75 & $3927(38 \%)$ & $3737(37 \%)$ & $3806(41 \%)$ & $3806(45 \%)$ & $3819(40 \%)$ \\
R50 & $3478(43 \%)$ & $2606(53 \%)$ & $3369(46 \%)$ & $3653(46 \%)$ & $3277(47 \%)$ \\
Eto (mm) & $1235(31 \%)$ & $1188(32 \%)$ & $1256(30 \%)$ & $1161(30 \%)$ & $1210(31 \%)$ \\
Rainfall (mm) & $281(66.0 \%)^{*}$ & $285(33.9 \%)^{*}$ & $217(38.3 \%)^{*}$ & $183(35.8 \%)^{*}$ & $242(44.6 \%)^{*}$ \\
\hline
\end{tabular}

( ): pre-harvest period percentage (January to mid May); ( $)^{*}$ in rainfall pre-harvest period percentage was from previous October to mid May. 
irrigation water applied since amount was small and very irregular his annual deal both. The normal cultivation practices as in the commercial orchard were followed.

The time taken over manual tasks, winter and summer pruning, thinning and harvesting was also measured, as was the time used for phytosanitary treatments and other tasks applied to the basic plot. The same fertilization was applied to all the plots to avoid any variability that might otherwise be introduced: $125 \mathrm{~kg} \cdot \mathrm{ha}^{-1} \mathrm{~N}, 55 \mathrm{~kg} \cdot \mathrm{ha}^{-1} \mathrm{P}_{2} \mathrm{O}_{5}$ and $210 \mathrm{~kg} \cdot \mathrm{ha}^{-1} \mathrm{~K}_{2} \mathrm{O}$.

\subsection{Cost-Benefit Analysis and Productive and Socioeconomic Water Use Efficiency}

We used costs accounting [25,26] to calculate several economic indices and, from these, to make a costs analysis. The net margin (NM) $[26,27]$ was obtained as the difference between incomes and costs, representing the pre-tax profits. As microeconomic indicators we used $\mathrm{NM} /$ investment $\left(\mathrm{NM} / \mathrm{K}_{0}\right), \mathrm{NM} /$ total costs $(\mathrm{NM} / \mathrm{C})$, viability threshold (VT) or cost production and break-even point (BEP) $[16,25]$. The break-even point is the minimum price per kilogram of product that is compatible with the viability of the activity, that is, the mean cost of production. The same parameter also indicates the minimum production for a given selling price that is compatible with the viability of the activity.

Other indices useful for analyzing the efficiency of irrigation water use were determined, given the importance of this limited a resource in the Mediterranean Basin. These were water use efficiency expressed as kg produced $/ \mathrm{m}^{3}$, gross productivity or gross incomes $/ \mathrm{m}^{3}[22,28]$, net margin $/ \mathrm{m}^{3}$ or economic efficiency. Also as an indicator of the social importance of water, the number of agricultural jobs (NAJ) associated with every $\mathrm{hm}^{3}$ of water consumed and the NAJ ha ${ }^{-1}$ to estimate the social importance of this crop in relation to others. This social efficiency of water, proposed by some author as the ratio generated employment/consumed water [22], is also used by [24] in specific studies for fruit trees in Murcia. Lastly, the maximum price of water below which the business to generate positive results, or water viability (WVT) $[8$, 29].

The costs and incomes for each treatment were calculated for the 2007, 2008, 2009 and 2010 campaigns; the economic analysis is a comparative analysis between several irrigation levels, with the same hypothesis of selffinancing for all the treatments. The costs and incomes established are the mean for the four years of the experiment so that they are representative of an average production year. The amounts of water provided for the different treatments are shown in Table 1.

The fixed assets costs are the same for all the treatments and the useful life calculated was based on the experience of growers covering recent years as real half life. Table 2 shows the initial investment and the corresponding depreciation calculated by the lineal method or constant quotas.

$$
\text { Annual depreciation }=\frac{\text { Initial value }- \text { residual value }}{\text { Useful life }}
$$

All the costs include the corresponding opportunity cost, calculated as an alternative use of the capital invested in risk-free bank accounts (calculated as an interest of $1.5 \%$ according to current rates and taking into account inflation). The ownership and tenancy of the land was considered as non-depreciating fixed assets [26].

It should be noted that the purchase of equipment necessary for cultivation tasks - a $60-80 \mathrm{hp}$ tractor with the corresponding farm tools, 2000 litre tank and tipping trailer-since the depreciation of these goods solely for the orchard in question would make the activity unviable. Therefore, we take into consideration the farm machinery offered by external services or fellow growers. To calculate the employment generated, we establish a fixed salary cost of $14,250 € /$ year (including salary and social security) for 1840 hours of work per year $[8,24]$.

The cost of the irrigation water is the real price for the

Table 2. Investment and annual depreciation of early peach crop.

\begin{tabular}{|c|c|c|c|c|}
\hline & Initial value $(€)$ & Residual value $(€)$ & Useful life (years) & Depreciation $^{*}\left(€\right.$ year $\left.^{-1}\right)$ \\
\hline Shed for equipment and irrigation control & 1875 & 375 & 25 & 61 \\
\hline Irrigation equipment & 1350 & 0 & 15 & 91 \\
\hline Irrigation network & 1441 & 0 & 10 & 146 \\
\hline Planting & 2832 & 0 & 15 & 192 \\
\hline Various & 180 & 0 & 5 & 37 \\
\hline Reservoir & 8640 & 0 & 25 & 351 \\
\hline Investment $\left(€ \mathrm{ha}^{-1}\right)$ & & & 16,318 & \\
\hline
\end{tabular}

\footnotetext{
*Annual depreciation plus opportunity cost (1.5\%).
} 
four years of the study in the area $(0.195,0.195,0.210$, $0.220 € \mathrm{~m}^{-3}$, respectively). In turn, the incomes are calculated as a function of production and the weighted mean price of the different harvests ( 3 to 5 depending on the year) into which the total production is divided. The price per kilo of fruit (Pr Fr) produced for each irrigation level was obtained using the following formula:

$$
\operatorname{PrFr}=\frac{\mathrm{VFTr}}{\mathrm{PTr}}
$$

$\operatorname{VFTr}=$ Final value of the total crop per irrigation treatment.

$\mathrm{PTr}=$ Total production $(\mathrm{kg})$ per irrigation treatment.

$$
\begin{gathered}
\operatorname{VFTr}=\sum_{\mathrm{d}=1}^{4}\left[\sum_{\mathrm{b}=1}^{4}\left[\sum_{\mathrm{a}=1}^{6}\left[\sum_{\mathrm{c}=1}^{8}(\operatorname{Pr} \mathrm{c} \times \mathrm{Kc})\right]\right]\right] \\
\operatorname{PTr}=\sum_{\mathrm{d}=1}^{4}\left[\sum_{\mathrm{b}=1}^{4}\left[\sum_{\mathrm{a}=1}^{6} \mathrm{kt}\right]\right]
\end{gathered}
$$

$\mathrm{d}$ : number of harvesting days (1 - 5),

b: number of experimental blocks (4),

a: number of trees in each block (6),

c: number of commercial calibres (6 a 8),

Pr: price per kilogram of commercial calibre,

Kc: weight $(\mathrm{kg})$ of fruit for each calibre,

$\mathrm{Kt}$ : weight of total production per tree.

Table 3 shows the results obtained for the production and selling price (3(a) and 3(b), respectively). The price shown is the weighted mean price for each annual har- vest, considering the different qualities (commercial sizes) and, lastly, the final result for the global weighted mean price. The average production and global weighted price are average values used in the subsequent economic calculations. An economic analysis must use production and price mean values in order to obtain representative results. It is considered that four years included in this analysis establish a representative average year of an economic reality.

\section{Results and Discussion}

We are working with a variety "low chill" with flowering time between January ending and early February. His ripening time is in early or medium May. Then we have a variety that developed its fruit growth cycle at environmental conditions of low irrigation water requirements and high probability of cold temperatures, too.

Table 4 represents the cost accounting per productive unit established, both in absolute and in relative terms, indicating the relative importance of each of the costs with regard to the total. The accounting structure points to an intensive system that involves very high operating costs compared with fixed assets [16]. This underlines the fact that the activity in question must be cash-rich to cover annual operating costs. Fixed assets amount to $€ 877 /$ year/ha compared with operating costs of $€ 12,000$ / year/ha, that is, assets only account for $7 \%$ of the annual production costs, so that the operating costs are very high

Table 3. (a) Average yield of the period (2007-2010); (b) Annual weighted price and global weighted price of the period (2007-

\begin{tabular}{|c|c|c|c|c|c|}
\hline Treatment & $2007\left(\mathrm{~kg} \cdot \operatorname{tree}^{-1}\right)$ & $2008\left(\mathrm{~kg} \cdot \operatorname{tree}^{-1}\right)$ & $2009\left(\mathrm{~kg} \cdot \operatorname{tree}^{-1}\right)$ & $2010\left(\mathrm{~kg} \cdot\right.$ tree $\left.^{-1}\right)$ & Average production $\left(\mathrm{kg} \cdot \mathrm{ha}^{-1}\right)$ \\
\hline Control & $34.5 \mathrm{a}$ & $33.5 \mathrm{a}$ & 38,1 & 38.6 & 18,774 \\
\hline $\mathrm{R} 150$ & $30.5 \mathrm{~b}$ & $34.5 \mathrm{a}$ & 41.0 & 36.6 & 18,257 \\
\hline R75 & $32.4 \mathrm{ab}$ & $33.0 \mathrm{ab}$ & 38.9 & 37.4 & 17,627 \\
\hline \multirow[t]{2}{*}{ R50 } & $32.9 \mathrm{ab}$ & $29.6 \mathrm{~b}$ & 42.2 & 39.0 & 18,068 \\
\hline & $*$ & $*$ & n.s & n.s & n. s. \\
\hline
\end{tabular}
2010).

(a)

\begin{tabular}{|c|c|c|c|c|c|}
\hline Treatment & 2007 & 2008 & 2009 & 2010 & Global weighted price $\left(€ \mathrm{~kg}^{-1}\right)$ \\
\hline Control & $0.73 \mathrm{a}$ & $0.73 \mathrm{~b}$ & 1.01 & $0.95 \mathrm{a}$ & $0.86( \pm 0.15)$ \\
\hline $\mathrm{R} 150$ & $0.65 \mathrm{~b}$ & $0.69 \mathrm{~b}$ & 0.96 & $0.86 \mathrm{~b}$ & $0.79( \pm 0.14)$ \\
\hline R75 & $0.64 \mathrm{~b}$ & $0.78 \mathrm{a}$ & 0.95 & $0.80 \mathrm{~b}$ & $0.81( \pm 0.11)$ \\
\hline \multirow[t]{2}{*}{ R50 } & $0.69 \mathrm{ab}$ & $0.73 \mathrm{a}$ & 1.00 & $0.85 \mathrm{~b}$ & $0.81( \pm 0.16)$ \\
\hline & & & n.s. & & n.s. \\
\hline
\end{tabular}

Significance level: ${ }^{*}$ significative differences and n.s.: not significative differences (LSD test, p > 95\%).

(b)

Significance level: n.s.: not significative differences LSD test $(\mathrm{p}>95 \%)$. $( \pm)$ : standard error. 
Table 4. Cost accounting for each treatment (2007-2010).

\begin{tabular}{|c|c|c|c|c|c|c|c|c|}
\hline & \multicolumn{2}{|c|}{ Control } & \multicolumn{2}{|c|}{$\mathrm{R} 150$} & \multicolumn{2}{|c|}{ R75 } & \multicolumn{2}{|c|}{ R50 } \\
\hline & $\begin{array}{l}\text { Absolute } \\
\operatorname{cost}(€)\end{array}$ & $\begin{array}{l}\text { Relative } \\
\text { cost (\%) }\end{array}$ & $\begin{array}{l}\text { Absolute } \\
\operatorname{cost}(€)\end{array}$ & $\begin{array}{l}\text { Relative } \\
\text { cost (\%) }\end{array}$ & $\begin{array}{l}\text { Absolute } \\
\operatorname{cost}(€)\end{array}$ & $\begin{array}{l}\text { Relative } \\
\text { cost (\%) }\end{array}$ & $\begin{array}{l}\text { Absolute } \\
\operatorname{cost}(€)\end{array}$ & $\begin{array}{l}\text { Relative } \\
\text { cost (\%) }\end{array}$ \\
\hline Shed & 61 & $0.47 \%$ & 61 & $0.47 \%$ & 61 & $0.48 \%$ & 61 & $0.49 \%$ \\
\hline Irrigation equipment & 91 & $0.70 \%$ & 91 & $0.70 \%$ & 91 & $0.73 \%$ & 91 & $0.73 \%$ \\
\hline Irrigation network & 146 & $1.13 \%$ & 146 & $1.12 \%$ & 146 & $1.16 \%$ & 146 & $1.17 \%$ \\
\hline Planting & 192 & $1.48 \%$ & 192 & $1.48 \%$ & 192 & $1.52 \%$ & 192 & $1.53 \%$ \\
\hline Various & 37 & $0.28 \%$ & 37 & $0.28 \%$ & 37 & $0.29 \%$ & 37 & $0.29 \%$ \\
\hline Reservoir & 351 & $2.70 \%$ & 351 & $2.70 \%$ & 351 & $2.79 \%$ & 351 & $2.80 \%$ \\
\hline Fixed assets & 877 & $6.8 \%$ & 877 & $6.7 \%$ & 877 & $7.0 \%$ & 877 & $7.0 \%$ \\
\hline Annual pruning & 1.019 & $7.8 \%$ & 1.004 & $7.7 \%$ & 1.004 & $8.6 \%$ & 1.004 & $8.6 \%$ \\
\hline Machinery & 935 & $7.2 \%$ & 935 & $7.2 \%$ & 935 & $8.0 \%$ & 935 & $8.0 \%$ \\
\hline Phytosanitary products & 1.003 & $7.7 \%$ & 1.003 & $7.7 \%$ & 1.003 & $8.6 \%$ & 1.003 & $8.6 \%$ \\
\hline Fertilizers & 894 & $6.9 \%$ & 894 & $6.9 \%$ & 894 & $7.6 \%$ & 894 & $7.7 \%$ \\
\hline Herbicides & 115 & $0.9 \%$ & 115 & $0.9 \%$ & 115 & $1.0 \%$ & 115 & $1.0 \%$ \\
\hline Electricity & 157 & $1.2 \%$ & 176 & $1.3 \%$ & 131 & $1.1 \%$ & 113 & $1.0 \%$ \\
\hline Crop insurance & 864 & $6.7 \%$ & 842 & $6.5 \%$ & 816 & $7.0 \%$ & 839 & $7.2 \%$ \\
\hline Summer pruning & 1.017 & $7.8 \%$ & 1.017 & $7.8 \%$ & 1.017 & $8.7 \%$ & 1.017 & $8.7 \%$ \\
\hline Thinning & 2.512 & $19.3 \%$ & 2.512 & $19.3 \%$ & 2.512 & $21.5 \%$ & 2.512 & $21.5 \%$ \\
\hline Harvesting & 2.648 & $20.4 \%$ & 2.576 & $19.8 \%$ & 2.491 & $21.3 \%$ & 2.562 & $22.0 \%$ \\
\hline Irrigation & 945 & $7.3 \%$ & 1.058 & $8.1 \%$ & 783 & $6.7 \%$ & 674 & $5.8 \%$ \\
\hline Operating costs & 12.111 & $93.2 \%$ & 12.133 & $93.3 \%$ & 11.702 & $93.0 \%$ & 11.670 & $93.0 \%$ \\
\hline Total costs & $12.988^{*}$ & $100 \%$ & $13.011^{*}$ & $100 \%$ & $12.580^{*}$ & $100.0 \%$ & $12.547^{*}$ & $100.0 \%$ \\
\hline
\end{tabular}

*Production cost per hectare.

(93\%). All the treatments involve very similar production costs per unit area (ranging from $€ 12,547$ to $€ 13,011 / \mathrm{ha}$ ). Labour costs are the biggest costs in quantitative terms in peach crops in many areas of the world, including the Mediterranean region of Spain [1,2]. Of particular note in this respect are the relative importance of costs associated with thinning, harvesting and pruning [18,30,31], purely manual tasks, which in our case represent between $54 \%$ and $61 \%$ of production costs (Table 4). [1] found labour costs represented $52 \%$ of the total costs in Andalusia (Spain).

The water used for irrigation is extremely important for being a limiting production factor which determines, depending on how it is used, the real economics of an irrigated crop. However, as can be seen in Table 4, the relative cost of water (the sum of the cost of the water and associated electrical energy) represents only $8.5 \%$ of the total costs, falling to $6.8 \%$ in the greatest deficit treatment since the quantity of water used per hectare is very low and despite the fact although the cost of the water is high $\left(€ 0.21 \mathrm{~m}^{-3}\right)$ compared with other production areas. For example, in the Ebro basin the mean amount of water used in drip irrigated peach crops reaches $5865 \mathrm{~m}^{3} \cdot \mathrm{ha}^{-1}[28]$, that is, $1236 \mathrm{~m}^{3}$ per hectare less than the economically best treatment in our case, the control (Table 1). The price of the water used in our study (from the Tajo-Segura transfer system) is that which exists in the area at the present time and can reach up to $0.26 € \mathrm{~m}^{-3}$ [3]. However, it is common practice to use subterranean and desalinated water (costing in excess of $0.33 € \mathrm{~m}^{-3}$ ) to compensate for the deficit in the water supply.

Table 5 depicts the indicators used in the comparative economic analysis and, lastly, the indicators obtained and used for the analysis of irrigation water use efficiency (Table 6).

The economic indices used that use net margin show that all the alternatives are viable although the control 
Table 5. Indexes of economic assessment during 2007-2010.

\begin{tabular}{|c|c|c|c|c|}
\hline Treatment & $\mathrm{NM} / \mathrm{K}_{0}(\%)$ & $\mathrm{NM} / \mathrm{C}(\%)$ & Production cost $\left(€ \mathrm{~kg}^{-1}\right)$ & Break even point $\left(\mathrm{Kg} \cdot \mathrm{ha}^{-1}\right)$ \\
\hline Control & $19.9 \%$ & $23.6 \%$ & 0.69 & 15,350 \\
\hline R150 & $10.2 \%$ & $11.1 \%$ & 0.72 & 16,662 \\
\hline R75 & $10.5 \%$ & $12.8 \%$ & 0.71 & 15,713 \\
\hline $\mathrm{R} 50$ & $13.8 \%$ & $16.0 \%$ & 0.70 & 15,795 \\
\hline
\end{tabular}

Abbreviations: $\mathrm{NM} / \mathrm{K}_{0}$, net margin/investmet; $\mathrm{NM} / \mathrm{C}$, net margin/total cost.

Table 6. Indexes of water use efficiency during 2007-2010.

\begin{tabular}{ccccccc}
\hline Treatment & Productivity $\left(€ \mathrm{~m}^{-3}\right)$ & $\begin{array}{c}\text { Productive } \\
\text { effciciency }\left(\mathrm{kg} \cdot \mathrm{m}^{-3}\right)\end{array}$ & $\begin{array}{c}\text { Economic } \\
\text { efficiency }\left(€ \mathrm{~m}^{-3}\right)\end{array}$ & $\mathrm{NAJ} \mathrm{ha}^{-1}$ & NAJ hm & WVT $\left(€ \mathrm{~m}^{-3}\right)$ \\
\hline Control & 3.58 & 4.10 & 0.74 & 0.60 & 130 & 0.95 \\
R150 & 2.89 & 3.57 & 0.34 & 0.59 & 0.5 & 116 \\
R75 & 3.75 & 4.62 & 0.45 & 0.58 & 153 & 0.63 \\
R50 & 4.51 & 5.54 & 0.65 & 0.59 & 181 & 0.82 \\
\hline
\end{tabular}

Abbreviations: NAJ ha ${ }^{-1}$, Number of Agricultural Jobs per hectare; NAJ hm ${ }^{-3}$, Number of Agricultural Jobs per cubic hectometre; WVT, water viability threshold.

with its $\mathrm{NM} / \mathrm{C}$ of $23.6 \%$ is of particular note. This is followed by R50, the highest deficit treatment, with an $\mathrm{NM} / \mathrm{C}$ of $16.0 \%$. The lower figure in this case is the result of lower production (3.8\% less than the control) and, especially, to the lower caliber fruit and therefore lower weighted average price $(-5.8 \%)$. A similar finding for deficit treatments was mentioned by [12] and was also evident in our R150 treatment. In all cases the $\mathrm{NM} / \mathrm{K}_{0}$ index was lower tan the $\mathrm{NM} / \mathrm{C}$, pointing to a high long term profitability but with a large initial investment (€16,318€) as seen from Table 5 .

The mean production cost was almost identical in the optimal treatment (control) and the R50 deficit treatment, $€ 0.69$ and $€ 0.70$, respectively, and very similar to those found in other studies of early varieties [1]. Lastly, in our cultivation conditions and prevailing market conditions, the minimum quantity that must be produced to make the operation viable (the break-even point) is $15,350 \mathrm{~kg} \cdot \mathrm{ha}^{-1}$ for the control, a figure substantially below the mean production achieved in recent years [16]. Indeed, taking into consideration the break-even point, all the treatments could be regarded as being amply productive. Despite using the greatest amount of water, treatment R150 was the least profitable and competitive, with a mean production cost of $€ 0.72 \mathrm{~kg}^{-1}$ and high break-even point.

In reference to the analysis of the efficiency of water as input, Table 6 shows the overall water use efficiency, that is, the indicators of productive, economic and social efficiencies. Although apparent productivity and production efficiency were greater in the deficit treatments than in the control, the economic efficiency of the control was substantially higher than that of the treatments. R50, for example, showed high economic efficiency that was close to that of the control $\left(0.65\right.$ and $0.74 € \mathrm{~m}^{-3}$, respectively). The gross economic index or water productivity (WP) index has been used for several crops, and sometimes as a comparative index between crops [28,32,33] or between different irrigation strategies in the same crop [34]. In our case, the deficit irrigation treatments were the most productive, reaching $4.51 € \mathrm{~m}^{-3}$ in $\mathrm{R} 50$. The least productive in terms of water use was R150 at $2.89 €$ $\mathrm{m}^{-3}$. These values are above those mentioned by [16] in early peach crops $\left(2.62 € \mathrm{~m}^{-3}\right)$.

The water use efficiency (WUE) is the most widely used index in the related scientific literature on a variety of crops $[8,29,35,36]$. In our case, R50 was the most efficient treatment, with a WUE of $5.54 \mathrm{~kg} \cdot \mathrm{m}^{-3}$, which is even better than the most favourable result found by [12] in peaches in California $\left(4.14 \mathrm{~kg} \cdot \mathrm{m}^{-3}\right)$, by [15] in Italy $\left(4.69 \mathrm{~kg} \cdot \mathrm{m}^{-3}\right)$ or [28] in the Ebro basin in Spain $(4.1$ $\left.\mathrm{kg} \cdot \mathrm{m}^{-3}\right)$. This confirms that all the treatments we describe strictly control the quantity of water used (Table 1).

The use of $\mathrm{MN} \mathrm{m} \mathrm{m}^{-3}$ as efficiency index reflects the benefit generated per $\mathrm{m} 3$ of water. This was greatest in the control $\left(0.74 € \mathrm{~m}^{-3}\right)$, followed by R50 $\left(0.65 € \mathrm{~m}^{-3}\right)$ while the other treatments were far from these figures. The most inefficient in this respect was the treatment that used most water (R150). [28] found the net economic productivity water in peach to be $0.74 € \mathrm{~m}^{-3}$. Of all growth in of Murcia, late peach varieties were the least efficient, the medium late and late varieties presenting 
values of 0.33 and $0.37 € \mathrm{~m}^{-3}$, respectively [16].

Peach cultivation generates a lot of employment, and in all cases, the NAJ ha ${ }^{-1}$ was around 0.59 (only taking into consideration production and harvesting), which is higher than figures for irrigated vine (0.12) or agriculture in general (0.05) [37]. As regards the social efficiency of water, that is, the employment generated per hectometer of water used, this indicator has also been used in other studies such as that of the [38], which considers the horticultural sector of Murcia in general. The deficit treatments we applied reached high values in this respect, reaching $181 \mathrm{NAJ} \mathrm{hm}^{-3}$ in R50, while the control figure

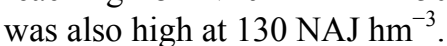

Lastly, the WVT is the maximum price of water that the activity can withstand and remain profitable. This is a very important index in arid and semiarid areas where water is in short supply and expensive, with a tendency to increase. This index, therefore, indicates which irrigation strategies and crops are competitive in given circumstances. The control treatment in our case was the most competitive and could support prices of up to $€ 0.95$ $\mathrm{m}^{-3}$. The WVT obtained highlights the fact that early peach varieties in south-eastern Spain do not have a very close dependence on the price of water. It is the availability of water, rather than its price, that is important, at least at the prices paid at the present time.

\section{Conclusions}

Irrigation water is an important production factor because of its limited supply, and its management largely determines the economics of an irrigated plantation.

The water cost for early peach growing has a minor importance in relation to the total production costs, while labour costs are determining. This is due to the low water consumption and the high demand on labour for thinning, pruning, and harvesting, and it is based on the productive and vegetative characteristics of early peach varieties.

All of the tested irrigation strategies turned out to be economically viable, being the control the most profitable of them. There were no high differences in production and in calibre, and the fruit weighted prices were relatively high for all.

Water use efficiency was seen to be very high both in productive and socio-economic terms. These varieties generate very high gross incomes, and show substantial employment needs, hence the activity we describe in this study can be considered as a contribution to the continuation of rural life and its welfare.

\section{Acknowledgements}

We are grateful to the company CARRILLO AGRICOLA S.L. for lending its installations and to the personnel of its "Pera pera" farm (Blanca, Murcia) for car- rying out the work described in this study.

\section{REFERENCES}

[1] C, Pirazzoli and D. Regazzi, "La Peschicoltura in Europa: Sistemi Produttivi a Confronto," Informatore Agrario, Vol. 55, No. 31, 1999, pp. 45-51.

[2] F. Alvisi, C. Malagoli, C. Pirazzoli and D. Regazzi, "Economic Aspect of Peach Growing in the Mediterranean Area," Medit, Vol. 6, No. 2, 1995, pp. 35-38.

[3] D. Rigby, F. Alcón and M. Burton, "Supply Uncertainty and the Economic Value of Irrigation Water," European Review of Agricultural Economics, Vol. 37, No. 1, 2010, pp. 97-117. http://dx.doi.org/10.1093/erae/jbq001

[4] P. D. Mitchell and D. J. Chalmers, "The Effect of Reduced Water Supply on Peach Tree Growth and Yields," Journal of the American Society for Horticultural Science, Vol. 64, 1982, pp. 541-552.

[5] J. Girona, "Regulated Deficit Irrigation in Peach. A Global Analysis," Acta Horticulturae, Vol. 592, No. 1, 2002, pp. 335-342.

[6] A. Naor, "Irrigation Scheduling and Evaluation of Tree Water Status in Deciduous Orchards," Horticultural Reviews, Vol. 32, 2006, pp. 111-166.

[7] J. García García, A. Martínez and P. Romero, "Financial Analysis of Wine Grape Production Using Regulated Deficit Irrigation and Partial-Root Zone Drying Strategies," Irrigation Science, Vol. 30, No. 3, 2011, pp. 179188. http://dx.doi.org/10.1007/s00271-011-0274-4

[8] J. García García, P. Romero, P. Botía and F. García, "Cost-Benefit Analysis of Almond Orchard under Regulated Deficit Irrigation (RDI) in SE Spain," Spanish Journal of Agricultural Research, Vol. 2, No. 2, 2004, pp. 157-165.

[9] D. J. Chalmers, P. D. Mitchell and L. A. G. Vanheek, "Control of Peach Tree and Productivity by Regulated Water Supply, Tree density and Summer Pruning," Journal of the American Society for Horticultural Science, Vol. 106, No. 3, 1981, pp. 307-312.

[10] C. H. Crisosto, R. S. Johonson, J. G. Luza and G. M. Crisosto, "Irrigation Regimes Affect Fruit Soluble Solids Concentration and Rateo f Water Loss of 'O' Henry' peaches," HortScience, Vol. 29, No. 10, 1994, pp. 1169-1171.

[11] J. Girona, "Physiological, Growth and Production Responses of Late Maturing Peach (Prunus persica L. Batsch) to Controlled Deficit Irrigation," MS Thesis, University of California, Davis, 1989.

[12] D. A. Goldhamer, M. Salinas, C. Crisosto, K. R. Day, M. Soler and A. Moriana, "Effects of Regulated Deficit Irrigation and Partial Root Zone Drying on Late Harvest Peach Tree Performance," Acta Horticulturae, Vol. 592, 2002, pp. 343-350.

[13] S. H. Li, J. G. Huguet, P. G. Schoch and P. Orlando, "Response of Peach Tree Growth And Cropping to Soil Water Deficit at Various Phenological Stages of Fruit Development," Journal of Horticultural Sciences, Vol. 64, No. 5, 1989, pp. 541-552.

[14] C. Xiloyannis, R. Massai and B. Dichio, "L'acqua e la 
tecnica dell'irrigazione," In: C. Fideghelli, S. Sansavini, Eds., Il pesco, Edagricole, Bologna, 2005, pp. 145-171.

[15] B. Dichio, C. Xiloyannis, A. Sofo and G. Montanaro, "Effects of Post-Harvest Regulated Deficit Irrigation on Carbohydrate and Nitrogen Partitioning, Yield Quality and Vegetative Growth of Peach Trees," Plant and Soil, Vol. 290, No. 1-2, 2007, pp. 127-137. http://dx.doi.org/10.1007/s11104-006-9144-x

[16] J. García García and J. García Brunton, "Eficiencia Económica del Agua de Riego en el Cultivo de Diferentes Grupos Varietales de Melocotón," Fruticultura Profesional, Vol. 172, 2008, pp. 28-139.

[17] D. Brochet, "Production et Conditionnement de la Peche: des Strategies et des Couts," L'Arboriculture fruitière, Vol. 512, 1998, pp. 28-30.

[18] T. M. De Jong, W. Tsuji, J. F. Doyle and Y. L. Grossman, "Comparative economic efficiency of four peach production systems in California," HortScience, Vol. 34, No. 1, 1999, pp. 73-78

[19] C. Martínez, F. Pardo, J. Castro and P. Tobarra, "Situación Actual de los Recursos Hídricos. Estructura Económica de la Región de Murcia,” Civitas, Madrid, 1993.

[20] F. Cabezas, "Balances Recursos-Demandas en la Cuenca del Segura. Diagnóstico de Problemas Hidrológicos. Agua y Futuro en la Región de Murcia," Campobell, Murcia, 1995, pp. 393-405.

[21] C. Martínez Gallur, P. Tobarra, J. P. Castro, F. J. Pardo, "Análisis económico del agua, principalmente subterránea, para uso agrícola. Agua y futuro en la Región de Murcia," Campobell, Murcia, 1995.

[22] I. Hussain, H. Turral, D. Molden and M. Ahmad, "Measuring and Enhancing the Value of Agricultural Water in Irrigated River Basins," Irrigation Science, Vol. 25, No. 3, 2007, pp. 263-282. http://dx.doi.org/10.1007/s00271-007-0061-4

[23] P. Segura, "El Agua Para Riego en Regiones Semiáridas. Riego Deficitario Controlado," Mundi Prensa, Murcia, 1995, pp. 15-42.

[24] J. García García, "Evaluación económica y eficiencia del agua de riego en frutales de regadío," Consejería de Agricultura y Agua, Murcia, 2007, 115 p.

[25] R. Layard and S. Glaister, "Cost-benefit Analysis," Cambridge University Press, Cambridge, 1994, 497 p. http://dx.doi.org/10.1017/CBO9780511521942

[26] E. Ballestero, "Economía de la Empresa Agraria y Alimentaria," Mundi-Prensa, Madrid, 2000, 416 pp.

[27] MAPA (Ministerio de Agricultura, Pesca y Alimentación), "Análisis de la economía de los sistemas de producción. Resultados técnico-económicos de explotaciones hortofrutícolas de la Comunidad Valenciana en 1998," Subsecretaría de Agricultura, Pesca y Alimentación, MAPA, Madrid, 1999, $165 \mathrm{p}$.
[28] R. Salvador, A. Martínez-Cob, J. Cavero and E. Playán, "Seasonal on-Farm Irrigation Performance in the Ebro Basin (Spain): Crops and Irrigation Systems," Agricultural Water Management, Vol. 98, No. 4, 2011, pp. $577-$ 587. http://dx.doi.org/10.1016/j.agwat.2010.10.003

[29] P. Romero Azorín, J. García García and P. Botía Ordaz, "Cost-Benefit Analysis of a Regulated Deficit-Irrigated Almond Orchard under Subsurface drip Irrigation Conditions in South-Eastern Spain," Irrigation Science, Vol. 24, No. 3, 2006, pp. 175-184 http://dx.doi.org/10.1007/s00271-005-0008-6

[30] Y. L. Grossman and T. M. De Jong, "Training and Pruning System Effects on Vegetative Growth Potential, Light Interception and Cropping Efficiency in Peach Trees," Journal of the American Society for Horticultural Science, Vol. 123, No. 6, 1998, pp. 1058-1064

[31] R. P. Marini and D. S. Sowers, "Peach Tree Growth, Yield and Profitability as Influenced by Tree for and Tree Density," HortScience, Vol. 35, No. 5, 2000, pp. 837-842

[32] E. Fereres, D. A. Goldhamer and L. R. Parsons, "Irrigation Water Management of Horticultural Crops," HortScience, Vol. 38, No. 5, 2003, pp. 1036-1042.

[33] J. F. Ortega, J. A. De Juan, J. M. Tarjuelo and E. López, "Mopeco: An Economic Optimization Model for Irrigation Water Management," Irrigation Science, Vol. 23, No. 2, 2004, pp. 61-75 http://dx.doi.org/10.1007/s00271-004-0094-x

[34] D. S. Intrigliolo, J. R. Castel, "Response of Vitis Vinifera cv. 'Tempranillo' to Partial Root-Zone Drying in the Field: Water Relations, Growth, Yield and Fruit and Wine Quality," Agricultural Water Management, Vol. 96, No. 2, 2009, pp. 282-292. http://dx.doi.org/10.1016/j.agwat.2008.08.001

[35] S. A. Alkhamisi, H. A. Abdelrahman, M. Ahmed and M. F. A. Goosen, "Assessment of Reclaimed Water Irrigation on Growth, Yield, and Water-Use Efficiency of Forage Crops," Applied Water Science, Vol. 1, No. 1-2, 2011, pp. 57-65. http://dx.doi.org/10.1007/s13201-011-0009-y

[36] J. S. Neal, W. J. Fulkerson and B. G. Sutton, "Differences in Water-Use Efficiency among Perennial Forages Used by the Dairy Industry under Optimum and Deficit Irrigation," Irrigation Science, Vol. 29, No. 3, 2011, pp. 213 232.

[37] CEE, "Hacia un Sector Vitivinícola Europeo," Informe de la Comisión europea, Junio 2006, 27 p. http://ec.europa.eu/spain/pdf/sectorvitivinicola_es.pdf

[38] CESRM (Consejo Económico y Social de la Región de Murcia), "Informe sobre la situación hidrológica y socioeconómica en la Cuenca del Segura en el nuevo contexto del Plan Hidrológico Nacional,”2000, 42 pp. 